Int. Agrophys., 2021, 35, 197-208

INTERNATIONAL

\title{
Effectiveness of the use of urease inhibitors in agriculture: a review**
}

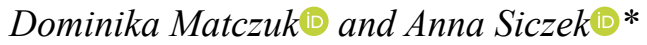 \\ Institute of Agrophysics, Polish Academy of Sciences, Doświadczalna 4, 20-290 Lublin, Poland
}

Received April 17, 2021; accepted July 2, 2021

\begin{abstract}
A b s t r a c t. Urea is one of the most popular fertilizers in the world. In 2018, the global production capacity of urea reached the level of 210 million metric tonnes. Due to the fact that the world population is growing steadily, the demand for food is increasing, and thus also the consumption of urea. The use of urea-based fertilizers has negative consequences in the form of ammonia volatilization. The solution to this problem may be the use of urease inhibitors. Currently, inhibitors of synthetic origin are available on the market, while the use of inhibitors of natural origin is still being under trial. The use of the most commonly used urease inhibitor - NBPT together with urea causes a reduction in ammonia emissions and has a beneficial effect on crop productivity. At the same time, the search for inhibitors of natural origin is underway, which, apart from reducing ammonia volatilization into the atmosphere, could have a positive effect on crop yields. In this paper, recent advances in this field are reviewed.

K e y w o r d s: soil urease, urea, urease inhibitors, ammonia volatilization
\end{abstract}

\section{INTRODUCTION}

Urea fertilizer usage is growing constantly. Apart from its wide-ranging application in agriculture, there are also new opportunities for its use, for example, in animal feeds and in manufacturing processes (Gilbert et al., 2006). Urea has a high $\mathrm{N}$ content (46\%), the production costs are relatively low and more importantly, it is easily available in the

*Corresponding author e-mail: a.siczek@ipan.lublin.pl

**This work was funded by the Ministry of Science and Higher Education, Poland, grant number DWD/3/51/2019 and by the statutory activities of the Institute of Agrophysics, Polish Academy of Sciences, Poland. market. The application of urea is also undemanding. Urea is a universal fertilizer for foliar fertilization and, above all, for soil fertilization. It can be used in the cultivation of most plants, pre-sowing and top dressing, as well as for foliar application in an aqueous solution (as urea ammonium nitrate, UAN) with a concentration adapted to the requirements of the species being fed and the plant's development phase (Chen et al., 1994; Guardia et al., 2018).

The nitrogen from urea is absorbed by plant roots and leaves. The ammonium formed after hydrolysis has a favourable effect on the harmonious growth and development of plants, supports phosphorus uptake and reduces excessive potassium uptake. This form of nitrogen supports favourable root growth and the proper development of plants from the post-emergence period increases their resistance and, above all, contributes to a high yield with a good biological value (Claussen and Lenz, 1995). Unfortunately, its tendency to volatize, inter alia, during and after application, and contaminate the environment makes it less efficient (Chunmei et al., 2020; Drury et al., 2017; Mulyani et al., 2001; Papangkorn et al., 2008). According to Wesołowska et al. (2021), the volatilization losses amount to a level of $11.5 \%$ in arable land and even $23 \%$ on grassland.

Urea is typically applied to the soil in the form of granules. In contact with the soil water, it dissolves within a short time. The dissolution rate of the granules depends on two

(C) 2021 Institute of Agrophysics, Polish Academy of Sciences 
main factors: the content of the soil water and temperature. The hydrolysis reaction of urea is catalysed by soil urease enzyme (Kissel and Cabrera, 2005).

Nitrogen is an element essential for life and occurs in the soil in many forms. Moreover, it undergoes many transformations, all of them contribute to the nitrogen cycle. The primary source of nitrogen in the biosphere is the atmosphere. The first stage of the whole biogeochemical cycle is the transformation of the gaseous form of nitrogen into chemical compounds, which can be processed further by living organisms. The role of microorganisms in the course of various ongoing natural processes is essential. Bacteria of the genera Rhizobium, Bradyrhizobium, Sinorhizobium, Mesorhizobium are examples of symbiotic nitrogen assimilators. Nitrogen can be assimilated by non-symbiotic microorganisms living freely in soils, both anaerobic and aerobic genera such as Azotobacter, Azospirillium, Clostridium, Arthrobacter, Pseudomonas, Aerobacter, Flavobacterium, Azomonas, Bacillus, Beijerinckia and cyanobacteria (especially Anabaena and Nostoc). Among the diazotrophes, some have been successfully used in biofertilizers to deliver $\mathrm{N}$ to crops (Chittora et al., 2020; Veresoglou and Menexes, 2010). The second source of nitrogen in soil are mineral fertilizers, which are also partly derived from the atmospheric $\mathrm{N}$ pool (i.e. ammonia production in the Haber-Bosch process). Moreover, nitrogen can also be made available for plant and microorganism growth from organic $\mathrm{N}$ sources, after their mineralization process. Examples of such organic materials are: animal manures, organic wastes as well as crop residues. Crop residues differ in their $\mathrm{N}$ content and legumes are far more rich in $\mathrm{N}$ compared to non-leguminous plants (Kalembasa et al., 2020).

Some forms of $\mathrm{N}$ are pollutants, therefore transformations which occur in the soil can affect human health and the state of the environment (Robertson and Groffman, 2015). There are certain factors which may have a two-fold influence on the occurrence of nitrogen transformations. Some of them are the results of human activity, for example, the type and composition of fertilizers used or the cultivation method used, while other factors depend entirely on the environment. $\mathrm{NH}_{3}$ which occurs in the soil is prone to volatilization to the atmosphere. There are several reasons for that phenomenon. The most significant impact on the quantity of $\mathrm{NH}_{3}$ gaseous losses are produced by the following factors: soil $\mathrm{pH}$, temperature and the concentration of the $\mathrm{NH}_{4}{ }^{+}$cation in the soil, water content and soil texture (Fenn and Hossner, 1985; Follet, 2008). Also, as mentioned previously, the cultivation method has an impact on the level of ammonia losses. Using mulch on no-tillage or pasture systems can cause larger losses, especially when the manure is applied to the surface of the soil (de Campos Bernardi et al., 2014). At present, the subject of ammonia losses is receiving a significant amount of attention due to certain requirements, which are set by the European Parliament.
All of these activities are connected to the fact that ammonia may be harmful if its concentration is too high. It can have an adverse effect on the following categories of life: agriculture, human health and ecosystems. The current requirements for fertilizer producers and farmers enforce activities leading to a reduction in ammonia volatilization. The main reasons for these changes are related to a desire to protect the natural environment.

\section{FACTORS AFFECTING AMMONIA VOLATILIZATION}

Zhenghu and Honglang (2000) have described several factors affecting ammonia volatilization. The results showed that the following are very important factors: soil $\mathrm{pH}, \mathrm{CaCO}_{3}$ and total salt content, but the most important factor was soil $\mathrm{pH}$. They selected 22 samples representing very different $\mathrm{pH}$ values (the values fluctuated between 4.32 and 9.12), the experiment utilizing these samples lasted for 10 days. They noted that the higher the $\mathrm{pH}$ was, the greater the degree of ammonia volatilization. The same insight concerning the correlation between $\mathrm{pH}$ and ammonia volatilization was arrived at by Shan et al. (2015) after 3 years of research. Gil et al. (2008) explained the relationship between these values - the higher $\mathrm{pH}$ directly influences the equilibrium between $\mathrm{NH}_{4}^{+}$and $\mathrm{NH}_{3}$.

The amount of released ammonia increases in proportion to the temperature (He, 1999). Clay et al. (1990) stated that in a field experiment, the amount of volatilized ammonia achieved its highest values two days after the urea was applied. The ammonia volatilization rate corresponded with the daily maximum soil temperature.

The cation exchange capacity (CEC) is the value referring to all of the cations that can be held, absorbed or exchanged in the soil. This value refers to the total amount of negatively charged particles existing in the surface of the soil. CEC influences the structural stability of the soil, the nutrient availability, $\mathrm{pH}$ and the way it reacts to fertilizers. The increase in CEC has an influence on the increase in the availability of basic cations which are necessary for a desirable amount of plant growth (Reeza et al., 2009). One example of a soil with a cation exchange capacity that has a high value is soil with a high amount of clay or organic matter (Sidi et al., 2015; Zhao et al., 2020). Zhenghu and Honglang (2000) observed a significant correlation between soil CEC and ammonia volatilization. The increase in the values of CEC in different kinds of soil results in the inhibition of ammonia volatilization (Sommer et al., 2004). This is due to the fact that the $\mathrm{NH}_{4}{ }^{+}$ion concentration decreases over time, so there is less of a chance for it to volatilize, moreover the increase in $\mathrm{pH}$ buffering capacity also contributes to this (Ferguson et al., 1984). The CEC factor is one of the most important factors in regulating the level of ammonia volatilization (Pelster et al., 2018). 
The method of application of fertilizer plays an undeniably large role in ammonia emissions. There are two methods of application of granulated fertilizers. The first one, which is the most common, is spreading the fertilizer on the soil surface. The second one is apply a dose of the fertilizer under the soil surface. Utilizing this method results in lower ammonia emissions (Klimczyk et al., 2021).

Two types of cultivation system were compared by Marchesan et al. (2013) - no-tillage and conventional during the application of urea coated with urease inhibitor. A reduction in $\mathrm{NH}_{3}$ volatilization was observed in both methods used, however, more substantial reductions in $\mathrm{NH}_{3}$ losses were achieved with conventional cultivation. In notill cultivation, there are many plant residues, their presence makes the fertilizer and inhibitor less effective.

In recent times, more and more publications have become available which are dedicated to biochar and its role in the process of ammonia volatilization from soils. Biochar is a porous material rich in carbon, which is produced by biomass pyrolysis. Many studies have presented the positive influence of the application of biochar into the soil. The benefits of such practices include an increase in crop yield and enhanced pesticide degradation (Das et al., 2020; Ding et al., 2017; Peiris et al., 2019). The research conducted proves that biochar has an accelerating effect on $\mathrm{NH}_{3}$ volatilization in saline soils. This is due to the fact that the $\mathrm{NH}_{3} / \mathrm{NH}_{4}^{+}$adsorption capacity of biochar is reduced by salt ions occurring in saline soils (Zhu et al., 2020). However, in the case of paddy soils, the application of biochar reduces the amount of ammonia released. This fact was proven in a field experiment carried out during one rice growing season. Scientists have compared the level of ammonia volatilization in two cases: using either straw or biochar. The application of biochar resulted in a lower cumulative ammonia volatilization level of about $20 \%$ (Sun et al., 2019). The results demonstrate that the positive (reduction in ammonia volatilization) or undesirable (increase in ammonia volatilization) impact of biochar depends on the type of the soil that it is applied to.

\section{UREASE}

Urease, urea amidohydrolase, is an enzyme from the class of hydrolases which catalyses the decomposition of urea into ammonia and carbon dioxide. This process is accelerated by the presence of the enzyme. Urea hydrolysis occurs in two steps. In the first one, urea is converted into ammonium carbonate by hydrolysis. The second step is to dissociate the ammonium carbonate, the products of which are ammonium ions and carbon dioxide:

$$
\begin{gathered}
\mathrm{CO}\left(\mathrm{NH}_{2}\right)_{2}+2 \mathrm{H}_{2} \mathrm{O} \rightarrow\left(\mathrm{NH}_{4}\right)_{2} \mathrm{CO}_{3}, \\
\left(\mathrm{NH}_{4}\right)_{2} \mathrm{CO}_{3}+\mathrm{H}^{+} \rightarrow 2 \mathrm{NH}_{4}^{+}+\mathrm{OH}^{-}+\mathrm{CO}_{2} .
\end{gathered}
$$

The ammonium ions formed as a result of this reaction are a source of nitrogen for bacteria. They are subjected to nitrification processes, as a result of which nitrites and nitrates are obtained, which are an excellent source of nitrogen for plants. Urease plays a key role in the nitrogen cycle in nature. Without its participation, urea could accumulate in the environment, which would disturb nitrogen circulation in nature.

Urease was the first enzyme to be obtained in a crystalline form. This was accomplished in 1926 by the American chemist James Sumner, who isolated urease from Canavalia ensiformis, in which it is especially abundant. He received the Nobel Prize for this achievement.

In order to understand why some substances have an inhibitory effect on urease, it is necessary to know its structure. A unique factor which differentiates it from other hydrolytic enzymes is the fact that urease is dependent on nickel ions. The first structure of urease to be presented was three-dimensional (Jabri et al., 1995). It consists of four structural domains, one of which is a bi-nickel centre. Other components of the active site are: carbamylated lysine, four histidine and aspartate residues. Moreover, one of the nickel ions is coordinated by three ligands, while the second one is coordinated by five ligands. In 1975 it was found that the presence of nickel ions is necessary for urease catalytic activity (Kappaun et al., 2018). Carbon dioxide is required for the activation of urease apoenzyme. The urea ligated to the Ni-1 in order to complete its tetrahedral coordination, and a hydroxide ligand of $\mathrm{Ni}-2$ attacks the carbonyl carbon (Jabri et al., 1995).

The sources of urease are plants, algae, bacteria, fungi and soil (Kafarski and Talma, 2018). Since it was isolated for the first time from Canavalia ensiformis (Fabaceae), it has been used as a model in the development of new urease inhibitors, which can be used in both agriculture and medicine.

Urease inhibitors may be categorized according to their mode of action. The first group is represented by compounds that bind directly to the nickel ions, which are present in the active centre of the urease enzyme. Examples of these compounds are NBPT, NPPT, 2-NPT, PPD and hydroxyurea. The representatives of the second group are hydroquinone and allicin, which binds to the active centre of the enzyme, which in turn leads to the formation of stable inhibitor complexes, which cause the loss of catalytic activity. In this case, a bond is formed between the inhibitor and a "flap" cysteine residue, which is located close to the dinickel active centre. Another example of the urease inhibiting mechanism is the binding of thiol compounds to the active site of the enzyme, which in turn leads to the formation of mixed disulphides. Newly created compounds contain cysteine residues, which play a very important role in the inhibition process. $\mathrm{KMnO}_{4}$ is an example of a potent oxidizer, which may be capable of reacting with the -SH group (which forms a part of the mobile "flap" 
cysteine residue). The oxidation of the - $\mathrm{SH}$ group affects the inhibition of enzyme activity. There is another group of potential urease inhibitors, the activity of which is based on their influence on the active centre of the enzyme. These are metal ions, for example $\mathrm{Ag}^{+}$, which modify the mobile "flap" cysteine. The final group is represented by metal ion chelators, which inhibit the formation of the dinickel centre (Modolo et al., 2018; Svane et al., 2020).

\section{SYNTHETIC UREASE INIHIBITORS}

Urease inhibitors can slow down the transformation of amide to ammonium hydroxide and ammonia or completely inhibit this process. The complete inhibition of urease activity has been described in examples of inknut extract and accacia extract by Fernando and Roberts (1976). The ingredients of these extracts responsible for the effectiveness of inhibition where polyphenols.

The gradual inhibition of the hydrolysis of urea contained in soil reduces the amount of ammonia released into the atmosphere (i.e. reduces ammonia losses). Due to this, the urea itself becomes more effective, the same effect is obtained in other nitrogen-based fertilizers containing urea. The other advantage of using urease inhibitors is that the level of pollutants released into the environment is lower (Kiss, 2002; Li et al., 2017).

The release of ammonia makes the use of fertilizers less effective. In order to increase the activity of the fertilizers used in agriculture, producers strive to broaden their knowledge concerning the use of appropriate inhibitors. Various urease inhibitors are available on the EU market (examples of synthetic and natural inhibitors are presented in Fig. 1), however, according to many authors, NBPT (N- (n-butyl) thiophosphoric triamide) is the most effective example among the various inhibitors at slowing down the microbial decomposition of urea (Cantarella et al., 2018; Silva et al., 2017). NBPT is the only urease inhibitor which is significant at the present time due to its availability on the market and its practical value to agriculture. The NBPT inhibitor is an additive to fertilizer urea, which temporarily slows down its enzymatic transformation by inhibiting urease activity. The use of urea with the addition of NBPT causes a smaller $\mathrm{pH}$ increase than when the urea is used alone, without the addition of inhibitor ( $\mathrm{Fu}, 2020)$. It may be added to the urea melt before granulation, applied to granule surfaces in a continuous or batch process, and also added to the UAN (urea ammonium nitrate) solution. NBPT is a non-toxic and odourless compound. The way it reacts with urease is through binding with two nickel ions and oxygen originating from the carbamate bridge. This activity reduces the risk that urea will reach the nickel ions (Klimczyk et al., 2021).

According to various studies, the reduction in gaseous ammonia emissions under the influence of even a small addition of NBPT is at the level of about $60 \%$ (Cantarella $e t$ al., 2018). Studies reported by Wang et al. (2020) showed that using NBPT can reduce $\mathrm{NH}_{3}$ volatilization by $50 \%$. The effectiveness of reducing ammonia emissions with an inhibitor depends on several factors, including the type of soil and cultivation system, and also the climate conditions (Klimczyk et al., 2021). In an experiment with five different inhibitors (two urease inhibitors and three nitrification inhibitors), the use of NBPT together with urea postponed the $\mathrm{NH}_{3}$ emission peak from 3 to 4 days. Moreover, the value obtained was still lower than the value which was reached in the case of the use of urea alone (Wang et al., 2020). According to Watson et al. (1994) the percentage

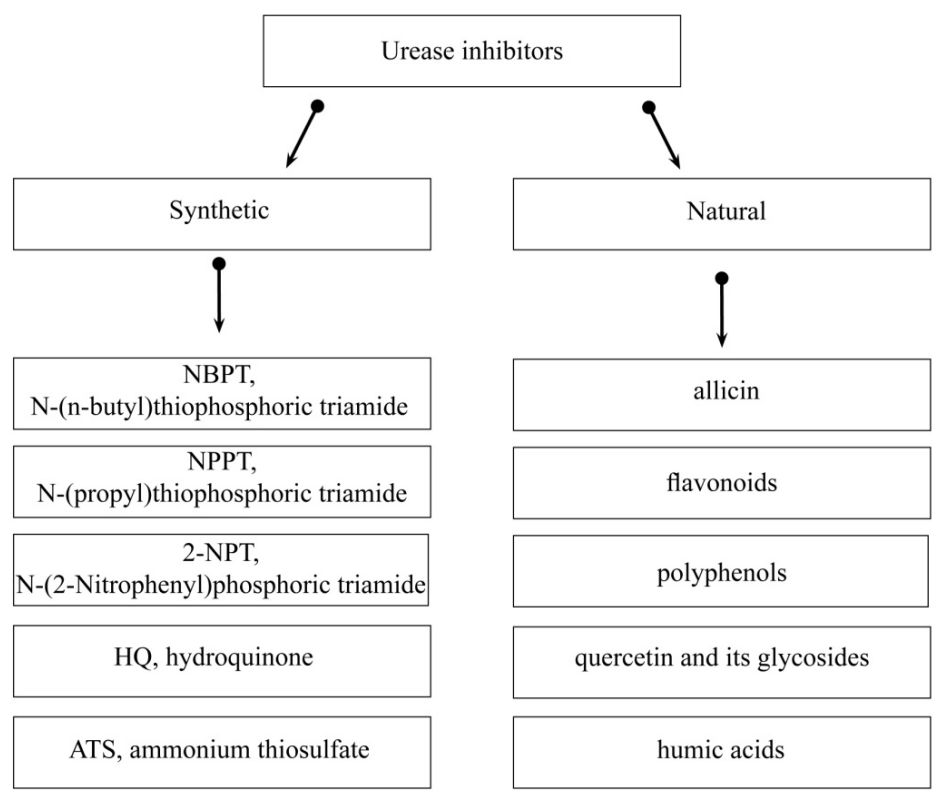

Fig. 1. Examples of synthetic and natural inhibitors. 
inhibition of $\mathrm{NH}_{3}$ loss by NBPT is highly dependent on the soil type. The most significant efficiency of that inhibitor was observed in soils with both a high $\mathrm{pH}$ and a low organic matter content. An experiment was conducted in which the influence of soil moisture was tested. In an incubation experiment, NBPT and PPDA (phenyl phosphorodiamidate) were applied with urea under three different soil moisture conditions. After analysing the results, the scientists concluded that the most promising water-filled pore space size (WFPS) was $60 \%$. The level of inhibition of urease enzyme activity obtained under these conditions was $75 \%$. The tests conducted with $40 \%$ WFPS found it to be irrelevant, while with $80 \%$ WFPS NBPT had no effect (Sanz-Cobena et al., 2013).

Another example of a substance that exhibits urease inhibiting properties is $\mathrm{N}$-(propyl) thiophosphoric triamide (NPPT). It has been proven that the use of this substance reduces the risk of nitrogen losses in the form of ammonia emissions after the application of fertilizers containing urea, and therefore increases the efficiency of nitrogen application. When applied together with urea the result was an approximately $50 \%$ lower amount of emitted ammonia when compared to urea alone (Modolo et al., 2018). However, the ability of NPPT to inhibit urease enzyme activity is still lower than in the case of NBPT.

There are reports of another substance that exhibits urease inhibitory properties. The main advantage of N-(2Nitrophenyl) phosphoric triamide (2-NPT) seems to be its stability. It is more stable than NBPT, which may degrade at high temperatures. The use of 2-NPT causes a remarkable decrease in $\mathrm{NH}_{3}$ emissions. After 19 days of the incubation of the samples which consisted of urea alone and the urease inhibitor combined with urea, a reduction in $\mathrm{NH}_{3}$ losses at the level of $89 \%$ was observed in the case of samples of urea combined with 2-NPT (Ni et al., 2018).

Another compound with urease inhibitory properties is hydroquinone (HQ). The advantage of this inhibitor is its cost effectiveness. During the 6-year field study on $\mathrm{N}_{2} \mathrm{O}$ emissions urea was applied in combination with HQ and DCD (dicyandiamide, a nitrification inhibitor). The results of $\mathrm{N}_{2} \mathrm{O}$ emission studies showed that there was a decrease in emissions by approximately $26.4 \%$ through HQ + DCD application (Dong et al., 2018). A similar study described by Wang et al. (2015) revealed a 16\% decrease in emissions, as compared to urea treatment. During the experiment reported by Dong et al. (2018) a number of factors were studied ( $\mathrm{N}$ application rate, soil organic matter content, soil moisture, temperature, the freeze-thaw cycle). Therefore, there was no significant impact from using a mixture of inhibitors together with urea on the content of different forms of nitrogen $\left(\mathrm{NH}_{4}{ }^{+}-\mathrm{N}, \mathrm{NO}_{3}{ }^{-} \mathrm{N}\right)$ occurring in the soil. Also, there was no significant impact on grain yield. However, a significant difference in maize biomass was observed. An upward trend has been observed.
Ammonium thiosulfate (ATS) in a mixture with urea-ammonium nitrate (UAN) results in the inhibition of urease at different levels varying from 18 to $48 \%$ (Sullivan and Havlin, 1992). The factors that have an effect on the efficiency of that inhibitor are such soil properties as: $\mathrm{pH}$, the content of clay, organic $\mathrm{C}$ and carbonate content. The temperature factor was also important. In a study reported by Sullivan and Havlin (1992), two temperatures (20 and $30^{\circ} \mathrm{C}$ ) were compared. It was noted that a higher temperature promoted a greater degree of urease inhibition. The other factors positively affecting the inhibition of urea hydrolysis were a low content of clay and organic carbon in the soil samples and a low soil moisture content.

\section{NATURAL UREASE INHIBITORS}

Allicin is an organic sulphur compound, which is obtained from garlic. The enzyme alliinase coverts alliin into allicin when fresh garlic is chopped or crushed. Allicin is responsible for the unique aroma of fresh garlic. It exhibits bactericidal properties against numerous bacteria, both gram-negative and gram-positive, and has antifungal and antiviral properties (Ankri and Mirelman, 1999). Due to its chemical structure, it reacts chemically with thiol groups belonging to various enzymes. Because of this, it was suspected that it might become a good urease inhibitor. An experiment carried out by Mathialagan et al. (2017) has presented the negative effect of garlic extract on the activity of urease derived from Jack Bean seeds. The aim of the experiment was to investigate the effect of allicin on the process of urease degradation from urea. Allicin solutions in 3 concentrations: 5, 10 and 15\% weight of allicin to weight of urea, and a solution of the synthetic inhibitor NBPT were used. The use of a $5 \%$ allicin solution produced the optimal urease inhibition result (among the allicin solutions used). However, in comparing the efficiency of a $5 \%$ allicin solution with NBPT, the obtained result was almost $75 \%$ lower.

In another experiment reported by Shabana et al. (2010), the positive effect of using a methanol-based onion extract on the inhibition of urease (obtained from Jack Bean seeds) activity has been described. Quercetin and its glycosides were isolated from onion and guava and their impact on the urease enzyme was observed. Researchers managed to achieve the inhibition of urease activity at a level of $53 \%$ for quercetin and $48 \%$ for avicularin.

Another example of a group of substances that have urease inhibitory properties are flavonoids. Awllia et al. (2016) have tested a group of commercially available flavonoids. The results of their research studies are very promising. Most of the substances that they tested proved to be effective inhibitors. Flavonoids are a group of chemicals that contain -OH groups in their molecular structure. Most like$\mathrm{ly}$, it is the presence of a hydroxyl group in the molecules of the tested substances that produces their ability to inhibit 
urease. Scientists who have studied the chemical structure of the urease enzyme suspect that the $-\mathrm{OH}$ groups interact with nickel ions present in the active centre of the urease enzyme, causing it to be deactivated. The effectiveness of given flavonoids as inhibitors is demonstrated by the number of $\mathrm{OH}$ groups and their location in the molecule.

Research work concerning the search for new urease inhibitors is constantly being carried out. Given that fruit skins are production waste in many fruit processing companies, this would be a very good way of using the waste generated during the production process as a source of urease inhibitor. The urease inhibitory effect achieved by the researchers was reversible, and its effect depends on the concentration of polyphenols in the apple peel used. The higher the concentration of polyphenols in the fruit peel, the more effective the inhibition of urease activity was (Pastene et al., 2009). A confirmation of this information was also obtained by Fernando and Roberts (1976), who extracted polyphenols which occur naturally in black tea, Accacia decurrens bark, or Terminalia chebula seed coating.

Another example of a substance that can be used as a urease inhibitor and the use of which will have a positive effect on both soil and plants is humic acid. Humic acids are organic compounds, basically they are the organic fraction of soil, peat and coal. Their structure is characterized by plenty of acidic functional groups, whose presence cause a high exchange capacity and inhibits the activity of urease (Liu et al., 2019; Zhang et al., 2019). The use of humic acid facilitates the uptake of nutrients, simultaneous plant growth, the acidification of fertilizer microsites, and finally, it lowers ammonia volatilization. A huge advantage of the use of humic acid is the fact that it can be produced at a low cost from the residues resulting from coal mining.

Currently, numerous studies are being conducted to search for the effective urease inhibitors. At present, the vast majority of research efforts are devoted to conducting research into synthetic urease inhibitors. However, the sector dedicated to inhibitors of natural origin is booming, it is undeniable that this research is very important not only for the agricultural sector, but also for the medical one.

\section{EFFECTS OF FERTILIZERS WITH UREASE INHIBITORS ON CROPS}

Several publications describe the effect of urea-based fertilizers with urease inhibitors on cultivated plants. Some examples of such studies (including crop and soil $\mathrm{N}$ responses) are presented in Table 1. Despite the fact that $\mathrm{N}$-(n-butyl) thiophosphoric triamide is characterized by a reduction in ammonia volatilization by delaying the hydrolysis of urea (Lasisi et al., 2019; Martins et al., 2017), it also makes nitrogen more readily available to plants. The use of this inhibitor caused a significant increase in crop $\mathrm{N}$ uptake (by 33\%). This factor makes it possible to obtain higher yields (Hube et al., 2017). The meta-analysis of the studies (published between 1990 and 2014) performed by
Silva et al. (2017) indicated that NBPT-treated urea leads to an increase in major crop (including barley, ryegrass, white clover, wheat, rice, cotton, sugarcane, corn) yields by $5.3 \%$ in comparison with urea. What is more, this trend was noted for all of the analysed classes of soil $\mathrm{pH}\left(\right.$ in $\left.\mathrm{H}_{2} \mathrm{O}\right)$ (from the very acidic to alkaline), SOC contents (from $<1$ to $>2 \%$ ), and $\mathrm{N}$ rate (from $<80$ to $>160 \mathrm{~kg} \mathrm{ha}^{-1} \mathrm{~N}$ ).

In the experiments described by Dawar et al. (2012) two aspects of the application of urea with NBPT were investigated. The first one was the impact of NBPT on herbage yield, and the second was the method of fertilizer application. In particular, fine particle application (FPA) and application in the form of granules with the equivalent values. The study was performed in glasshouses, one cultivated plant was ryegrass. It was clearly stated that the use of an inhibitor together with a fertilizer brought about a significantly improved herbage yield when compared with other treatments. Moreover, the use of FPA also produced superior results. Nitrogen-response efficiency increased, and the herbage growth was improved. A deficiency of the use of NBPT inhibitor is the fact that it may cause leaf-tip scorch. However, it is reassuring that those effects may be short-lived and reversible (Trenkel, 2010).

Dewi et al. (2018) have conducted field experiments in the area which have been characterized by a very low fertility rate and content of organic matter in the soil. The impact of the application of urea coated with a mixture of NBPT and NPPT on maize was analysed. By observing the photosynthetic and transpiration rates as well as the fresh and dry weight of crops, it was concluded that using the correct dose of urea in conjunction with an inhibitor, allows for the attainment of improved yields. It is worth noting that the use of a lower dose of fertilizer $\left(278 \mathrm{~kg} \mathrm{ha}^{-1}\right)$ with inhibitors produced better effects than when a dose of $348 \mathrm{~kg} \mathrm{ha}^{-1}$ was used. Additionally, the plants treated with urea coated with inhibitors showed a higher chlorophyll content and transpiration rate. These factors influenced the ability of the plant to photosynthesize. In turn, Martins et al. (2017) noted in a field trial the enhanced urea- ${ }^{15} \mathrm{~N}$ recovery by maize (in grain and straw) and an increased grain yield (by 10\%) when the plants were treated with urea and thiophosphoric triamide (NBPT).

In fact, urease inhibitors delay the process of urea hydrolysis and give plants the opportunity to absorb urea for a longer period of time. Plant can absorb urea through both their roots and leaves. Therefore, the use of urease inhibitors results in different advantages. It reduces $\mathrm{N}$ losses in the form of ammonia volatilization, and increases bioavailability at the same time (Dawar et al., 2011; Li et al., 2015; Marchesan et al., 2013; Zaman et al., 2009). In addition, a field lysimeter experiment showed increased herbage dry matter production (by 38\%) and a higher amount of ${ }^{15} \mathrm{~N}$ recovery in the shoots for NBPT treatment as compared to treatments without a urease inhibitor (Dawar et al., 2011). Pasture parameters were also improved through the 
Table 1. Selected studies on crop and $\mathrm{N}$ responses after application of urea-based fertilizers with urease inhibitors

\begin{tabular}{|c|c|c|c|}
\hline Crop type & Crop response & Soil nitrogen response & References \\
\hline \multicolumn{4}{|c|}{ NBPT } \\
\hline $\begin{array}{l}\text { Rice } \\
(\text { Oryza sativa })\end{array}$ & $\begin{array}{l}\text { grain yield response dependent on season } \\
\text { and intervals of water intake in } \\
\text { conventional system and higher or not } \\
\text { changed in no-till system, increase or } \\
\text { decrease or not changed the concentration } \\
\text { of total } \mathrm{N} \text { in plants dependent on season } \\
\text { and water intake, no difference in } \\
\text { chlorophyll content }\end{array}$ & $\begin{array}{l}\text { slower and reduced losses by } \\
\text { ammonia volatilization (magnitude of } \\
\text { the effectiveness of inhibitors was } \\
\text { associated with soil, season, climate } \\
\text { conditions, and cultivation system), } \\
\text { slowed and delayed conversion of } \mathrm{N} \\
\text { to } \mathrm{NH}_{3} \text { in no-till system (from } 34-96 \\
\text { to } 216 \mathrm{~h} \text { ), reduced volatilization } \\
\text { losses for no-till (from } 28 \text { to } 18 \% \text { ) } \\
\text { and conventional tillage (from } 11 \text { to } \\
7 \% \text { ) }\end{array}$ & $\begin{array}{l}\text { Marchesan et al., } \\
2013\end{array}$ \\
\hline $\begin{array}{l}\text { Barley } \\
\text { (Hordeum vulgare L.) }\end{array}$ & $\begin{array}{l}\text { increased stand density at } \mathrm{N} \text { levels, } \\
\text { increased final yield in } 4 \text { of } 5 \text { site-years, } \\
\text { increased the amount of } \mathrm{N} \text { that can be } \\
\text { safely placed with the seed (without } \\
\text { seedling damage risk), no changes in dry } \\
\text { matter yield at heading }\end{array}$ & not determined & $\begin{array}{l}\text { Grant and Bailey, } \\
1999\end{array}$ \\
\hline $\begin{array}{l}\text { Rice (variety Apo and } \\
\text { Hanyou3 (hybrid with } \\
\text { tolerance to drought)) }\end{array}$ & $\begin{array}{l}\text { improved plant growth and seed } \\
\text { germination (from } 9.32 \text { to } 16.22 \% \text { for } \\
\text { Apo and from } 17.76 \text { to } 36.81 \% \text { for } \\
\text { Hanyou3) }\end{array}$ & reduced ammonia volatilization & Qi et al., 2012 \\
\hline $\begin{array}{l}\text { Cotton } \\
\text { (Gossypium hirsutum } \\
\text { L.) }\end{array}$ & $\begin{array}{l}\text { improved } \mathrm{N} \text { uptake }(17 \%) \text { and } \mathrm{N} \text { use } \\
\text { efficiency }(41 \%) \text {, positive effect on leaf } \\
\text { chlorophyll content, plant growth and } \\
\text { fiber quality }\end{array}$ & not determined & $\begin{array}{l}\text { Kawakami et al., } \\
2012\end{array}$ \\
\hline $\begin{array}{l}\text { Winter wheat var. } \\
\text { Siskin }\end{array}$ & no changes in grain and straw yields & $\begin{array}{l}\text { exchangeable } \mathrm{NH}_{4}^{+} \text {not significantly } \\
\text { affected at } 2 \text { days after urea } \\
\text { application }\end{array}$ & Fu et al., 2020 \\
\hline $\begin{array}{l}\text { Wheat } \\
\text { (Triticum aestivum L.) }\end{array}$ & increased yield ( $7-11 \%)$ in 2 of 3 years & $\begin{array}{l}\text { reduced } \mathrm{N} \text { loss where seasonal } \\
\text { conditions were conducive to } \\
\text { volatilisation or denitrification later } \\
\text { in the season }\end{array}$ & Wallace et al., 2020 \\
\hline $\begin{array}{l}\text { Maize } \\
\text { (Zea mays L.) }\end{array}$ & $\begin{array}{l}\text { enhanced urea- }{ }^{15} \mathrm{~N} \text { recovery by maize (in } \\
\text { grain and straw, and in total amount of } \mathrm{N} \\
\text { from fertilizer in plant by } 46 \% \text { ), increased } \\
\text { maize grain yield by } 10 \%\end{array}$ & $\begin{array}{l}\text { NBPT delayed urea hydrolysis and } \\
\text { reduced the } \mathrm{NH}_{3} \text { volatilization by } \\
35 \%\end{array}$ & Martins et al., 2017 \\
\hline $\begin{array}{l}\text { Oat (Avena sativa L. } \\
\text { cv. Nehuén) }\end{array}$ & $\begin{array}{l}\text { increased crop yield (by } 27 \% \text { ) and crop N } \\
\text { uptake (by } 33 \% \text { ), greater } \mathrm{N} \text { use efficiency }\end{array}$ & $\begin{array}{l}\text { no significant effect of } \mathrm{NBPT} \text { on } \\
\text { average soil mineral } \mathrm{N} \text { concentration, } \\
\text { and total } \mathrm{N}_{2} \mathrm{O} \text { and } \mathrm{CH}_{4} \text { emissions }\end{array}$ & Hube et al., 2017 \\
\hline \multicolumn{4}{|c|}{ NBPT (Agrotain) } \\
\hline $\begin{array}{l}\text { Pastures ryegrass } \\
\text { (Lolium perenne L.) } \\
\text { with white clover } \\
\text { (Trifolium repens } \mathrm{L} . \text {.) }\end{array}$ & $\begin{array}{l}\text { increased herbage dry matter production } \\
\text { by } 38 \% \text {, higher }{ }^{15} \mathrm{~N} \text { recovery in the shoots }\end{array}$ & $\begin{array}{l}\mathrm{N}_{2} \mathrm{O} \text { emissions were reduced by } \\
7-12 \%, \mathrm{NH}_{3} \text { emissions by } 65-69 \% \\
\text { and } \mathrm{NO}_{3} \text {, leaching losses by } 36-55 \%\end{array}$ & Dawar et al., 2011 \\
\hline
\end{tabular}


Table 1. Continuation

\begin{tabular}{ll}
\hline Crop type & Crop response \\
\hline & \\
Wheat & no changes in plant heights, number of \\
(Triticum aestivum $\mathrm{L})$. & ears per square meter, 1000 grain \\
& weights, and harvest indexes, higher \\
& number of grains per ear, mass per \\
& hectoliter, and plant shoot dry mass, \\
& higher total shoot N accumulation \\
& $(17.24 \%)$, higher grain yield and N grain \\
& content, higher apparent N recovery \\
& $(42.26 \%)$ and N use efficiency (47.90\%)
\end{tabular}

Pasture: ryegrass

(Lolium perenne L.)

(80-85\%) and white

clover (Trifolium repens

L.) $15-20 \%$

\section{Ryegrass}

(Lolium perenne L.)

Maize (Zea mays L.)

Winter wheat

Maize (Zea mays L.) increased pasture dry matter (by 6, 9 and $6 \%$ ) and $\mathrm{N}$ uptake (by the 12, 20 and $8 \%$ ) depending on sampling time

increase in: dry matter (14-35\%), the N-response efficiency (31-96\%) and the total increase in $\mathrm{N}$ uptake (34-65\%) relative to other forms of fertilizers
Soil nitrogen response

References

Espindula et al., 2013

not determined

reduced $\mathrm{NH}_{3}$ emissions (by 29, 93

Zaman et al., 2009 and $31 \%$, depending on term), increase $(9.5 \%)$ or decrease $\mathrm{N}_{2} \mathrm{O}$ emission (by 16, $1.5 \%$ ) depending on term

delayed urea hydrolysis and thus released $\mathrm{NH}_{4}^{+}$at a slower rate

Dawar et al., 2012

\section{NBPT with NPPT}

improvement in: leaf chlorophyll content (4.26-12.77\%), photosynthetic rate (184$201 \%)$, transpiration rate (4.75-6.29\%), plant growth, total $\mathrm{N}$ content in leaves (40\%) roots, shoots and seeds, seed weight per ha, 100-seed weight, $\mathrm{N}$ absorption efficiency in relation to treatment without fertilizer

\section{NBPT with NPPT (Limus)}

increase in apparent $\mathrm{N}$ recovery efficiency (from 10 to $16 \%$ in relation to equal amounts of urea-N) and increase in $\mathrm{N}$ recovery up to $65 \%$ under a further $20 \%$ N-reduced urea amended with inhibitors, no effects on grain yields at three studied locations no changes in nitrate reductase activity

Dewi et al., 2018

reduced cumulative $\mathrm{NH}_{3}$ losses (11-25\% for plain urea compared to $0-6 \%$ from urea with inhibitor), increased fertilizer $\mathrm{N}$ retention more strongly when soil and environmental conditions promoted extensive $\mathrm{NH}_{3}$ losses

Humic acid

enhanced aboveground dry biomass (by $11.50-21.33 \%$ ), higher grain yields (by $5.58-18.67 \%$ ), higher uptake of fertilizer $\mathrm{N}$ (by 11.49-29.46\%) depending on humic acid fraction
$\mathrm{N}$ loss decreased by $12.37-30.05 \%$, no significant difference in the amount of total residual fertilizer $\mathrm{N}$ in soil columns $(0-90 \mathrm{~cm})$, decreased the amount residual fertilizer $\mathrm{N}$ in the $30-50 \mathrm{~cm}$ soil layer

Triple superphosphate, humic acid, fulvic acid not applicable reduced ammonia loss by 12.9 Shamsuddin et al., 2009 
use of a urease inhibitor (NBPT) in other studies through increased dry matter and $\mathrm{N}$ uptake relative to other forms of fertilizers (Dawar et al., 2012; Zaman et al., 2009). The extension of the time of urea decomposition in the soil causes a milder change in soil $\mathrm{pH}$ around the seeds. This, in turn, also promotes improved seed germination and root growth (Cantarella et al., 2018).

Marchesan et al. (2013) noted that the cultivation system used as well as the seasonal intervals of water intake have an impact on the effectiveness of NBPT as an inhibitor to rice grain yield. After comparing the no-tillage and conventional method they stated that in aerobic conditions NBPT is transformed into its oxygen analogue compound which leads to the delay and reduction in ammonia volatilization. The application of NBPT also has a positive impact on the root growth of rice seedlings (Qi et al., 2012).

The positive impact on the performance of wheat was noted when using NBPT in topdressing. By using this inhibitor with urea, improved plant parameters (number of grains, plant shoot dry mass, total shoot $\mathrm{N}$ accumulation, grain yield and $\mathrm{N}$ grain content) were obtained (Espindula et al., 2013). In other experiments with wheat, an increase in apparent $\mathrm{N}$ recovery and an increase in $\mathrm{N}$ recovery or increased yield in some seasons were observed ( $\mathrm{Li}$ et al., 2015; Wallace et al., 2020). However, no changes in the grain and straw yields of wheat were noted by $\mathrm{Fu}$ et al. (2020). In 3 years of conducting experiments using NBPT, Grant and Bailey (1999) observed an increase in the grain yield of barley. Moreover, it was noted that the use of NBPT lowers the risk of seedling damage. This in turn favours the more efficient use of nitrogen applied in the fertilizer. Moreover, oat yield and $\mathrm{N}$ uptake increased (by 27 and 33\%, respectively) when NBPT was applied (Hube et al., 2017).

The reduced $\mathrm{N}$ rate with urea + NBPT lead to improved cotton (Gossypium hirsutum L.) parameters by increasing $\mathrm{N}$ uptake and $\mathrm{N}$ use efficiency, as well as having a positive effect on the leaf chlorophyll content, plant growth and fibre quality (Kawakami et al., 2012).

The use of humic acids as urease inhibitors brings about many benefits related to the growth and properties of cultivated plants. Zhang et al. (2019) describe effects such as: an increase in the dry biomass of plants, higher grain yields, higher $\mathrm{N}$ uptake. The use of humic acid enhanced the dry biomass of the plants by up to $21 \%$ and caused higher yields of up to $18 \%$. Observation made by Shamsuddin et al. (2009) showed that the use of urea mixed with humic acids caused a reduction in ammonia losses and in effect a reduction in environmental pollution. The improvement in some soil properties was presented in a long-term experiment. The application of humic acid contributed to an improvement in cultivation efficiency in terms of better physicochemical properties, thereby increasing the diversity of soil-living microorganisms and the growth in enzymatic activities (Liu et al., 2019).

\section{EFFECTS OF UREASE INHIBITORS ON SOIL MICROORGANISMS}

There have been several reports in recent times concerning the impact of urease inhibitors on soil microorganisms, however, as yet, their effects are not well understood. According to the results presented by Fu et al. (2020), the use of NBPT together with urea did not have a significant effect on the abundance of bacteria, archaea and fungi as well as on the abundance of bacterial amoA gene copies (estimated using qPCR). However, the abundance of bacterial amoA transcripts decreased after NBPT addition on day 8 after application. The abundance of $\mathrm{N}$-cycling genes (bacterial ureC, bacterial amoA, Nitrospira nxr, archaeal amoA, Nitrobacter $n x r$ ) was at a similar level for the control and NBPT treatments. In another study, the AOB (ammonia oxidizing bacteria) amoA gene copy numbers significantly decreased (by 74\%) after the application of DCD (dicyandiamide) with HQ (hydroquinone), as compared to the control treatment, and the opposite reaction was noted with regard to the abundance of the AOA (ammonia oxidizing archaea) amo $A$ gene (Dong et al., 2018). The relative abundances of ammonia-oxidizing bacteria (AOB) and complete ammonia oxidizers (comammox Nitrospira), but not ammonia-oxidizing archaea (AOA) were significantly influenced by the application of NBPT, this suggests that NBPT inhibits the growth of AOB and comammox organisms in the soil (Luchibia et al., 2020).

\section{SUMMARY}

The substances with urease inhibiting properties presented in this review are the future of agricultural development. The inhibitors used to date, such as NBPT and NPPT are very effective, but as yet we do not have sufficient knowledge about the long-term impact on the environment of the use of these substances. According to the current observable trends in agriculture, substances of a natural origin that would also exhibit these properties are being sought. The use of plant extracts or plant residues seems to be a much-desired solution these days. There are many publications in which the effectiveness of natural urease inhibitors in the field of medicine has been proven. The number of publications concerning natural urease inhibitors that are used in agriculture is constantly growing. However, scientists still have many obstacles to overcome, for example: the isolation of natural inhibitors from plant material and the production of those inhibitors on a large scale, which will definitely be far more complicated than is the case with the currently known and used inhibitors.

Conflict of interest: The Authors do not declare any conflict of interest. 


\section{REFERENCES}

Ankri S. and Mirelman D., 1999. Antimicrobial properties of allicin from garlic. Microbes Infect., 1(2), 125-129. https://doi.org/10.1016/s1286-4579(99)80003-3

Awllia J.J.A., Al-Ghamdi M., Huwait E., Javaid S., Atia-tulWahab, Rasheed S., and Choudhary M.I., 2016. Flavonoids as natural inhibitors of jack bean urease enzyme. Letters in Drug Design and Discovery, 13, 243-249. https://doi.org/10.2174/1570180812666150914220050

Bernardi C.C., Mota E.P., Cardosa R.D., Monte M.B.M., and Oliveira P.P.A., 2014. Ammonia volatilization from soil, dry-matter yield, and nitrogen levels of Italian ryegrass. Communications in Soil Science and Plant Analysis, 45 (2), 153-162. https://doi.org/10.1080/00103624.2013.854804

Cantarella H., Otto R., Soares J.R., and Silva A.G.B., 2018. Agronomic efficiency of NBPT as a urease inhibitor: A review. J. Advanced Res., 13, 19-27. https://doi.org/10.1016/j.jare.2018.05.008

Chen D.L., Freney J.R., Mosier A.R., and Chalk P.M., 1994. Reducing denitrification loss with nitrification inhibitors following presowing applications of urea to a cotton field. Australian J. Exp. Agric., 34 (1), 75-83. https://doi.org/10.1071/ea9940075

Chittora D., Meena M., Barupal T., Swapnil P., and Sharma K., 2020. Cyanobacteria as a source of biofertilizers for sustainable agriculture. Biochem. Biophys. Rep., 22, 100737. https://doi.org/10.1016/j.bbrep.2020.100737

Chunmei X., Liping C., Song C., Guang C., Danying W., and Xiufu Z., 2020. Rhizosphere aeration improves nitrogen transformation in soil, and nitrogen absorption and accumulation in rice plants. Rice Sci., 27 (2), 162-174. https://doi.org/10.1016/j.rsci.2020.01.007

Claussen W. and Lenz F., 1995. Effect of ammonium and nitrate on net photosynthesis, flower formation, growth and yield of eggplants (Solanum melongena L.). Plant Soil, 171, 267274. https://doi.org/10.1007/bf00010281

Clay D.E., Malzer G.L., and Anderson J.L., 1990. Ammonia volatilization from urea as influenced by soil temperature, soil water content, and nitrification and hydrolysis inhibitors. Soil Sci. Soc. Am. J., 54 (1), 263-266.

https://doi.org/10.2136/sssaj1990.03615995005400010042x

Das S.K., Ghosh G.K., and Avasthe R., 2020. Application of biochar in agriculture and environment, and its safety issues. Biomass Conversion Biorefinery. https://doi.org/10.1007/s13399-020-01013-4

Dawar K., Zaman M., Rowarth J.S., Blennerhassett J., and Turnbull M.H., 2011. Urease inhibitor reduces N losses and improves plant-bioavailability of urea applied in fine particle and granular forms under field conditions. Agric., Ecosys. Environ., 144, 41-50. https://doi.org/10.1016/j.agee.2011.08.007

Dawar K., Zaman M., Rowarth J.S., and Turnbull M.H., 2012. Applying urea with urease inhibitor (N-(n-butyl) thiophosphoric triamide) in fine particle application improves nitrogen uptake in ryegrass (Lolium perenne L.). Soil Sci. Plant Nutr., 58 (3), 309-318.

https://doi.org/10.1080/00380768.2012.680050

Dewi F.C., Putra E.T.S., and Wulandari C., 2018. The effect of urease inhibitors coated urea on the growth, physiological activities and yield of maize (Zea mays L.) in inceptisol Jogonalan, Klaten. Ilmu Pertanian. Agric. Sci., 3 (3), 160165. https://doi.org/10.22146/ipas.32367
Ding Y., Liu Y., Liu S., Huang X., Li Z., Tan X., Zeng G., and Zhou L., 2017. Potential benefits of biochar in agricultural soils: a review. Pedosphere, 27 (4), 645-661. https://doi.org/10.1016/s1002-0160(17)60375-8

Dong D., Kou Y., Yang W., Chen G., and Xu H., 2018. Effects of urease and nitrification inhibitors on nitrous oxide emissions and nitrifying/denitrifying microbial communities in a rainfed maize soil: A 6-year field observation. Soil Till. Res., 180, 82-90. https://doi.org/10.1016/j.still.2018.02.010

Drury C.F., Yang X., Reynolds W.D., Calder W., Oloya T.O., and Woodley A.L., 2017. Combining urease and nitrification inhibitors with incorporation reduces ammonia and nitrous oxide emissions and increases corn yields. J. Environ. Quality, 46, 939-949. https://doi.org/10.2134/jeq2017.03.0106

Espindula M.C., Rocha V.S., Souza M.A., Campanharo M., and Sousa Paula G., 2013. Rates of urea with or without urease inhibitor for topdressing wheat. Chilean J. Agric. Res., 73 (2), 160-167.

https://doi.org/10.4067/s0718-58392013000200012

Fenn L.B. and Hossner L.R., 1985. Ammonia volatilization from ammonium or ammonium-forming nitrogen fertilizers. Advances Soil Sci., 1, 123-169.

https://doi.org/10.1007/978-1-4612-5046-3_4

Ferguson R.B., Kissel D.E., Koelliker J.K., and Basel E., 1984. Ammonia volatilization form surface-applied urea: effect of hydrogen ion buffering capacity. Soil Sci. Soc. Am. J., 48 (3), 578-582.

https://doi.org/10.2136/sssaj1984.03615995004800030022x

Fernando V. and Roberts G.R., 1976. The partial inhibition of soil urease by naturally occurring polyphenols. Plant Soil, 44, 81-86. https://doi.org/10.1007/bf00016957

Follet R., 2008. Chapter 2. Transformation and Transport Processes. Nitrogen in the Environment: Sources, Problems, and Management.

Fu Q., Abadie M., Blaud A. et al., 2020. Effects of urease and nitrification inhibitors on soil $\mathrm{N}$, nitrifier abundance and activity in a sandy loam soil. Biol. Fertil. Soils, 56, 185-194. https://doi.org/10.1007/s00374-019-01411-5

Gil M.V., Carballo M.T., and Calvo L.F., 2008. Fertilization of maize with compost from cattle manure supplemented with additional mineral nutrients. Waste Manag., 28 (8), 14321440. https://doi.org/10.1016/j.wasman.2007.05.009

Gilbert P.M., Harrison J., Heil C.A., and Seitzinger S., 2006. Escalating worldwide use of urea - a global change contributing to coastal eutrophication. Biogeochemistry, 77(3), 441-463. https://doi.org/10.1007/s10533-005-3070-5

Grant C.A. and Bailey L.D., 1999. Effect of seed-placed urea fertilizer and N-(n-butyl) thiophosphoric triamide (NBPT) on emergence and grain yield of barley. Canadian J. Plant Sci., 79 (4), 491-496. https://doi.org/10.4141/p98-121

Guardia G., Sanz-Cobena A., Sanchez-Martin L., FuertesMendizabal T., Gonzalez-Murua C., Alvares J.M., Chadwick D., and Vallejo A., 2018. Urea-based fertilization strategies to reduce yield-scaled $\mathrm{N}$ oxides and enhance bread-making quality in a rainfed Mediterranean wheat crop. Agric. Ecosys. Environ., 265, 1, 421-431. https://doi.org/10.1016/j.agee.2018.06.033

He Z.L., Alva A.K., Calvert D.V., and Banks D.J., 1999. Ammonia volatilization from different fertilizer sources and effects of temperature and soil pH. Soil Sci., 164(10), 750758. https://doi.org/10.1097/00010694-199910000-00006 
Hube S., Alfaro M.A., Scheer C., Brunk C., Ramirez L., Rowlings D., and Grace P., 2017. Effect of nitrification and urease inhibitors on nitrous oxide and methane emissions from an oat crop in a volcanic ash soil. Agric. Ecosys. Environ., 238, 46-54.

https://doi.org/10.1016/j.agee.2016.06.040

Jabri E., Carr M.B., Hausinger R., and Karplus P., 1995. The crystal structure of urease form Klebsiella aerogenes. Science (New York, N.Y.), 268, 998-1004. https://doi.org/10.1126/science.7754395

Kafarski P. and Talma M., 2018. Recent advances in design of new urease inhibitors: A review. J. Advanced Res., 13,101112. https://doi.org/10.1016/j.jare.2018.01.007

Kalembasa S., Szukała J., Faligowska A., Kalembasa D., Symanowicz B., Becher M., and Gebus-Czupyt B., 2020. Quantification of biologically fixed nitrogen by white lupin (Lupins albus L.) and its subsequent uptake by winter wheat using the ${ }^{15} \mathrm{~N}$ isotope dilution method. Agronomy, 10, 1392; https://doi.org/10.3390/agronomy10091392

Kappaun K., Piovesan A.R., Carlini C.R., and Ligabue-Braun R., 2018. Ureases: Historical aspects, catalytic, and noncatalytic properties - A review. J. Advanc. Res., 13, 3-17. https://doi.org/10.1016/j.jare.2018.05.010

Kawakami E.M., Oosterhuis D.M., Snider J.L., and Mozaffari M., 2012. Physiological and yield responses of field-grown cotton to application of urea with the urease inhibitor NBPT and the nitrification inhibitor DCD. Eur. J. Agron., 43, 147154. https://doi.org/10.1016/j.eja.2012.06.005.

Kiss S. and Simihặian M., 2002. Improving efficiency of urea fertilizers by inhibition of soil urease activity. Kluwer Academic Publishers; Doordrech.

https://doi.org/10.1007/978-94-017-1843-1

Kissel D.E. and Cabrera M.L., 2005. Ammonia. References Module in Earth Systems and Environmental Sciences. Encyclopedia Soils Environ., 56-64.

Klimczyk M., Siczek A., and Schimmelpfennig L., 2021. Improving the efficiency of urea-based fertilization leading to reduction in ammonia emission. Science of the Total Environment, 771. https://doi.org/10.1016/j.scitotenv.2021.145483

Lasisi A.A., Akinremi O.A., and Kumaragamage D., 2019. Efficacy of a new N-(n-butyl) thiophosphoric triamide formulation in reducing ammonia volatilization from ureabased fertilizers. Can. J. Soil Sci., 99, 395-405. https://doi.org/10.1139/cjss-2018-0072

Li Q., Cui X., Liu X., et al., 2017. A new urease-inhibiting formulation decreases ammonia volatilization and improves maize nitrogen utilization in North China Plain. Sci. Rep., 7. https://doi.org/10.1038/srep43853

Li Q., Yang A., Wang Z., Roelcke M., Chen X., Zhang F., Pasda G., Zerulla W., Wissemeier A.H., and Liu X., 2015. Effect of a new urease inhibitor on ammonia volatilization and nitrogen utilization in wheat in north and northwest China. Field Crops Res., 175, 96-105. https://doi.org/10.1016/j.fcr.2015.02.005.

Li X.G., Jia B., Lv J., Ma Q., Kuzyakov Y., and Li F., 2017. Nitrogen fertilization decreases the decomposition of soil organic matter and plant residues in planted soils. Soil Biology Biochem., 112, 47-55.

https://doi.org/10.1016/j.soilbio.2017.04.018
Liu X., Zhang M., Li Z., Zhang C., Wan C., Zhang Y., and Lee D.J., 2019. Inhibition of urease activity by humic acid extracted from sludge fermentation liquid. Bioresource Technol., 290. https://doi.org/10.1016/j.biortech.2019.121767

Luchibia A.O., Suter H., Hu H., Lam S.K., and He J.-Z., 2020. Responses of ureolytic and nitrifying microbes to urease and nitrification inhibitors in selected agricultural soils in Victoria, Australia. J. Soils Sediments, 20, 1309-1322. https://doi.org/10.1007/s11368-020-02562-x

Marchesan E., Grohs M., Walter M., da Silva L.S., and Formentini T.C., 2013. Agronomic performance of rice to the use of urease inhibitor in two cropping systems. Revista Ciência Agronômica, 44 (3).

https://doi.org/10.1590/s1806-66902013000300023

Martins M.R., Sant'Anna S.A.C., Zaman M., Santos R.C., Monteiro R.C., Alves B.J.R., Jantalia C.P., Boddey R.M., and Urquiaga S., 2017. Strategies for the use of urease and nitrification inhibitors with urea: Impact on $\mathrm{N}_{2} \mathrm{O}$ and $\mathrm{NH}_{3}$ emissions, fertilizer- ${ }^{15} \mathrm{~N}$ recovery and maize yield in a tropical soil. Agric. Ecosys. Environ., 247, 54-62. https://doi.org/10.1016/j.agee.2017.06.021

Mathialagan R., Mansor N., Al-Khateeb B., Mohamad M.H., and Shamsuddin M.R., 2017. Evaluation of Allicin as Soil Urease Inhibitor. Procedia Eng., 184, 449-459.

https://doi.org/10.1016/j.proeng.2017.04.116

Modolo L.V., da-Silva C.J., Brandão D.S., and Chaves I.S., 2018. A minireview on what we have learned about urease inhibitors of agricultural interest since mid-2000s. J. Advan. Res., 13, 29-37. https://doi.org/10.1016/j.jare.2018.04.001

Mulyani N.S., Suryadi M.E., Dwiningsih S., and Haryanto H., 2001. Nitrogen dynamics on rice field soils. J. Tanah dan Iklim, 19, 14-25.

Ni K., Kage H., and Pacholski A., 2018. Effects of novel nitrification and urease inhibitors (DCD/TZ and 2-NPT) on $\mathrm{N}_{2} \mathrm{O}$ emissions from surface applied urea: An incubation study. Atmosp. Environ., 75-82. https://doi.org/10.1016/j.atmosenv.2017.12.002

Papangkorn J., Isaraphan C., Phinhongthong S., Opaprakasit M., and Opaprakasit P., 2008. Controlled-release material for urea fertilizer from polylactic acid. Advan. Materials Res., 55-57, 897-900.

https://doi.org/10.4028/www.scientific.net/amr.55-57.897

Pastene E., Troncoso M., Figueroa G., Alarcon J., and Hernan S., 2009. Association between polymerization degree of apple peel polyphenols and inhibition of Helicobacter pylori urease. J. Agric. Food Chem., 57(2), 416-424. https://doi.org/10.1021/jf8025698

Peiris C., Gunatilake S.R., Wewalwela J.J., and Vithanage M., 2019. Chapter 11 - Biochar for Sustainable Agriculture: Nutrient Dynamics, Soil Enzymes, and Crop Growth. Biochar from Biomass and Waste, Fundamentals and Applications, 211-224. https://doi.org/10.1016/b978-0-12-811729-3.00011-x

Pelster D.E., Chantigny M.H., Angers D.A., Bertrand N., MacDonald J.D., and Rochette P., 2018. Can soil clay content predict ammonia volatilization losses from subsurface-banded urea in eastern Canadian soils? Canadian J. Soil Sci., 98(3): 556-565. https://doi.org/10.1139/cjss-2018-0036 
Qi X., Wu W., Shah F., Peng S., Huang J., Cui K., Liu H., and Nie L., 2012. Ammonia volatilization from urea-application influenced germination and early seedling growth of dry direct-seeded rice. The Scientific World J., https://doi. org/10.1100/2012/857472

Reeza A., Ahmed O., Majid N., and Jalloh M.B., 2009. Reducing ammonia loss from urea by mixing with humic and fulvic acids isolated from coal. Am. J. Environ. Sci., 5(3), 420-426. https://doi.org/10.3844/ajessp.2009.420.426

Robertson, G.P. and Groffman P.M., 2015. Nitrogen transformations. Soil microbiology, ecology and biochemistry. 421-446. Academic Press, Burlington, Massachusetts, USA. https://doi.org/10.1016/b978-0-12-415955-6.00014-1

Sanz-Cobena A., Abalos D., Meijide A. Sanchez-Martin L., and Vallejo A., 2013. Soil moisture determines the effectiveness of two urease inhibitors to decrease $\mathrm{N}_{2} \mathrm{O}$ emission. Mitigation Adaptation Strategies for Global Change, 21, 1131-1144. https://doi.org/10.1007/s11027-014-9548-5

Shabana S., Kawai A., Kai K., Akiyama K., and Hayashi H., 2010. Inhibitory activity against urease of quercetin glycosides isolated from Allium cepa and Psidium guajava. Biosci. Biotechnol. Biochem., 74 (4), 878-880. https://doi.org/10.1271/bbb.90895

Shamsuddin R., Osumanu H.A., and Nik M.A.M., 2009. Controlling ammonia volatilization by mixing urea with humic acid, fulvic acid, triple superphosphate and muriate of potash. Am. J. Environ. Sci., 5(5), 605-609. https://doi. org/10.3844/ajessp.2009.605.609

Shan L., He Y., Chen J., Huang Q., and Wang H., 2015. Ammonia volatilization from a Chinese cabbage field under different nitrogen treatments in the Taihu Lake Basin, China. J. Environ. Sci., 38, 14-23. https://doi.org/10.1016/j.jes.2015.04.028

Sidi N., Aris A.Z., Talib S.N., Johan S., Yusoff T.S.T.M., and Ismail M.Z., 2015. Influential factors on the cation exchange capacity in sediment of Merambong Shoal, Johor. Procedia Environ. Sci., 30, 186-189.

https://doi.org/10.1016/j.proenv.2015.10.033

Silva A.G.B., Sequeira C.H., Sermarini R.A., and Otto R., 2017. Ureaseinhibitor NBPT on ammonia volatilization and crop productivity: A meta-analysis. Agronomy J., 109(1), 1-13. https://doi.org/10.2134/agronj2016.04.0200

Sommer S.G., Schjoerring J.K., and Denmead O., 2004. Ammonia emission from mineral fertilizers and fertilized crops. Advances Agronomy, 82, 557-622. https://doi.org/10.1016/s0065-2113(03)82008-4

Sullivan D.M. and Havlin J.L., 1992. Soil and environmental effects on urease inhibition by ammonium thiosulfate. Soil Sci. Soc. Am. J., 56 (3), 950-956. https://doi.org/10.2136/ sssaj1992.03615995005600030044x

Sun X., Zhong T., Zhang L., Zhang K., and Wu W., 2019. Reducing ammonia volatilization from paddy field with rice straw derived biochar. Sci. Total Environ., 660, 512-518. https://doi.org/10.1016/j.scitotenv.2018.12.450

Svane S., Siguardson J.J., Finkenwirth F., Eitinger T., and Karring H., 2020. Inhibition of urease activity by different compounds provides insight into the modulation and association of bacterial nickel import and ureolysis. Sci. Report, 10, 8503. https://doi.org/10.1038/s41598-020-65107-9
Trenkel M.E., 2010. Slow- and controlled-release and stabilized fertilizers: An Option for Enhancing Nutrient Use Efficiency in Agriculture. Int. Fertilizer Industry Association: Paris, France, 61-67, 18-20.

Veresoglou S.D. and Menexes G., 2010. Impact of inoculation with Azospirillum spp. on growth properties and seed yield of wheat: a meta-analysis of studies in the ISI Web of Science from 1981 to 2008. Plant Soil, 337:469-480. https://doi.org/10.1007/s11104-010-0543-7

Wallace A.J., Armstrong R.D., Grace P.R., Scheer C., and Partington D.L., 2020. Nitrogen use efficiency of ${ }^{15} \mathrm{~N}$ urea applied to wheat based on fertiliser timing and use of inhibitors. Nutrient Cycling Agroecos., 116, 41-56. https://doi.org/10.1007/s10705-019-10028-x

Wang H., Köbke S., and Dittert K., 2020. Use of urease and nitrification inhibitors to reduce gaseous nitrogen emissions from fertilizers containing ammonium nitrate and urea. Global Ecol. Conserv., 22. https://doi.org/10.1016/j.gecco.2020.e00933

Wang X., Zhang L., Zou J., and Liu S., 2015. Optimizing net greenhouse gas balance of a bioenergy cropping system in southeast China with urease and nitrification inhibitors. Ecol. Eng., 83, 191-198. https://doi.org/10.1016/j.ecoleng.2015.05.047

Watson C.J., Miller H., Poland P., Kilpatrick D.J., Allen M.D.B., Garrett M.K., and Christianson C.B., 1994. Soil properties and the ability of the urease inhibitor N-(nBUTYL) thiophosphoric triamide (nBTPT) to reduce ammonia volatilization from surface-applied urea. Soil Biol. Biochem., 26 (9), 1165-1171. https://doi.org/10.1016/0038-0717(94)90139-2

Wesołowska M., Rymarczyk J., Góra R., Baranowski P., Sławiński C., Klimczyk M., Supryn G., and Schimmelpfennig L., 2021. New slow-release fertilizers - economic, legal and practical aspects: a Review. Int. Agrophys., 35, 11-24. https://doi.org/10.31545/intagr/131184

Zaman M., Saggar S., Blennerhassett J.D., and Singh J., 2009. Effect of urease and nitrification inhibitors on $\mathrm{N}$ transformation, gaseous emissions of ammonia and nitrous oxide, pasture yield and $\mathrm{N}$ uptake in grazed pasture system. Soil Biol. Biochem., 41, 1270-1280.

https://doi.org/10.1016/j.soilbio.2009.03.011

Zhang S., Yuan L., Li W., Lin Z., Li Y., Hu S., and Zhao B., 2019. Effects of urea enhanced with different weathered coal-derived humic acid components on maize yield and fate of fertilizer nitrogen. J. Integrative Agric., 18(3), 656666. https://doi.org/10.1016/s2095-3119(18)61950-1

Zhao T.X.Z., Arshad M., Li N., Zare E., and Triantafilis J., 2020. Determination of the optimal mathematical model, sample size, digital data and transect spacing to map CEC (Cation exchange capacity) in a sugarcane field. Computers Electronics Agric., 173. https://doi.org/10.1016/j.compag.2020.105436

Zhenghu D. and Honglang X., 2000. Effects of soil properties on ammonia volatilization. Soil Sci. Plant Nutr., 46(4), 845852. https://doi.org/10.1080/00380768.2000.10409150

Zhu H., Yang J., Yao R., Wang X., Xie W., Zhu W., Liu X., Cao Y., and Tao J., 2020. Interactive effects of soil amendments (biochar and gypsum) and salinity on ammonia volatilization in coastal saline soil. Catena, 190. https://doi.org/10.1016/j.catena.2020.104527 